\title{
Phenyl Polypropanoids from Lindelofia stylosa
}

\author{
Muhammad Iqbal Choudhary, ${ }^{*, a}$ Afshan Begum, ${ }^{a}$ Ahmed Abbaskhan, ${ }^{a}$ Asma Ajaz, ${ }^{a}$ \\ SHAFIQUE-UR-ReHMAN, ${ }^{b}$ and ATtA-UR-RAHMAN ${ }^{a}$ \\ ${ }^{a}$ H.E.J. Research Institute of Chemistry, International Center for Chemical Sciences, University of Karachi; Karachi- \\ 75270, Pakistan: and ${ }^{b}$ Department of Botany, University of Azad Jammu and Kashmir; Muzafarabad-13100, Pakistan. \\ Received May 2, 2005; accepted June 30, 2005
}

\begin{abstract}
A phytochemical investigation on the aerial parts of Lindelofia stylosa has resulted in the isolation of seven phenyl propanoids 1-7. This includes three analogs of lithospermic acid 1-3, along with rosmarinic acid (4) and its ester derivatives 5-7. Compound 1 was identified as a new natural product. These compounds were studied for their antioxidant properties.
\end{abstract}

Key words Lindelofia stylosa; rosmarininc acid; rosmarinate derivative; lithospermic acid; antioxidant activity

About ten species of genus Lindelofia (Boraginaceae) are found in Central and West Asia and in Himalayan regions of Pakistan. Lindelofia stylosa (KAR. \& KIR.) is a perennial herb reported to contain pyrrolizidine alkaloids. ${ }^{1-8)}$ In continuation of our studies on the biologically active phytochemicals, we investigated the whole herb of $L$. stylosa of Pakistani origin. The present work resulted in the isolation of compounds 1-7. The structures of the isolated compounds were elucidated mainly with the help of NMR spectroscopic techniques.

Three members of the phenyl propanoid class (compounds 1-3) were isolated from the EtOAc fraction of the plant which were identified to be the derivatives of lithospermic acid.

New compound $\mathbf{1}$ was isolated as a brown yellow gum. The compound showed an $\mathrm{M}^{+}$at $m / z 579.1493$ in HR-FABMS (-ve), in agreement with the formula $\mathrm{C}_{30} \mathrm{H}_{28} \mathrm{O}_{12}$ (Calcd 579.1502). Its IR spectrum showed the presence of an $\alpha, \beta$ unsaturated carbonyl system at $1722 \mathrm{~cm}^{-1}$. The overall spectral data of compound $\mathbf{1}$ closely resembled the known compound dimethyl lithospermate (2), ${ }^{9}$ the only difference between the two compounds being the appearance of signals for $\mathrm{O}-\mathrm{CH}_{2} \mathrm{CH}_{3}$ moiety in the NMR spectra of $\mathbf{1}$. The $\mathrm{O}-\mathrm{CH}_{2} \mathrm{CH}_{3}$ protons appeared as an $\mathrm{AB}$ quartet at $\delta 4.14$ $(J=14.2 \mathrm{~Hz}, J=7.0 \mathrm{~Hz})$, and a triplet at $\delta 1.19(J=7.0 \mathrm{~Hz})$, which corresponded to the carbons resonated at $\delta 62.4$ and 14.3 , respectively. This indicated that compound $\mathbf{1}$ is an ethyl ester of lithospermic acid.

Compound 2 exhibited an $\mathrm{M}^{+}$at $\mathrm{m} / \mathrm{z} 565.1343$ in the HR-FAB-MS (-ve), which corresponded to the formula $\mathrm{C}_{29} \mathrm{H}_{26} \mathrm{O}_{12}$ (Calcd 565.1346). The spectral data of compound 2 was found to be identical with the reported dimethyl lithospermate, which was first isolated from Salvia mitiorrhiza. ${ }^{9}$

Compound 3 showed an $\mathrm{M}^{+}$at $m / z 745.1766$ in the HRFAB-MS (-ve), suggestive of the formula $\mathrm{C}_{38} \mathrm{H}_{34} \mathrm{O}_{16}$ (Calcd 745.1768). The overall spectral data of compound 3 was identified as a known methyl ester derivative of lithospermic acid B, which was isolated from Salvia przewalskii. ${ }^{10)}$

The comparison of ${ }^{1} \mathrm{H}$ - and ${ }^{13} \mathrm{C}-\mathrm{NMR}$ data and physical data with those reported in the literature, indicated compounds 4-7 were esters of rosmarinic acid (4), ${ }^{11,12)} O$ methyl rosmarinate $(\mathbf{5}),{ }^{13)}$ ethyl rosmarinate $(\mathbf{6})^{14)}$ and butyl derivative (7). ${ }^{15)}$ Their isolation from L. stylosa is reported here for the first time.

* To whom correspondence should be addressed. e-mail: hej@cyber.net.pk
The isolated compounds $\mathbf{1}-\mathbf{7}$ were found to possess radical scavenging properties in DPPH radical assay, among which, compounds 3 and $\mathbf{4}$ have exhibited the strongest activities. The rosmarinic acid (4) was found to be as active as the standard (3-t-butyl-4-hydroxyanisole).

Compound $\mathbf{4}$ has been reported in previous studies to be potent antioxidant. ${ }^{16,17)}$ It increases the prostaglandin E2 production and reduces the production of leukotriene $\mathrm{B}_{4}$ in human polymorphonuclear leukocytes. ${ }^{18)}$ It is also an inhibitor of complement $\mathrm{C} 3$-convertase ${ }^{19,20)}$ as well as an inhibitor of lipid peroxidation. ${ }^{21)}$

Our results have indicated that the derivatives of lithospermic acid, possessing a C-19 lactate moiety, are more active than those without such substituents, such as compounds $\mathbf{1}$ and $\mathbf{2}$. The study of antioxidant potentials of compounds $\mathbf{1}-$ 7 was carried out by using $\mathrm{Fe}^{2+}$-chelating and superoxide scavenging assays. The results demonstrated the selectivity of compounds $\mathbf{3}-\mathbf{5}$ in these two assays, while the others were inactive. Interestingly, compound $\mathbf{3}$ has shown activity which is comparable to the standard propyl gallate used in the two assays. Our results demonstrated that the rosmarinate ester derivatives $4-5$ and compound 3 possess significant antioxidant activities in various assays (see Table 1).

\section{Experimental}

General Experimental Procedures Melting points were determined on a Yanaco apparatus. UV spectra were measured on a Shimadzu UV240 ma-
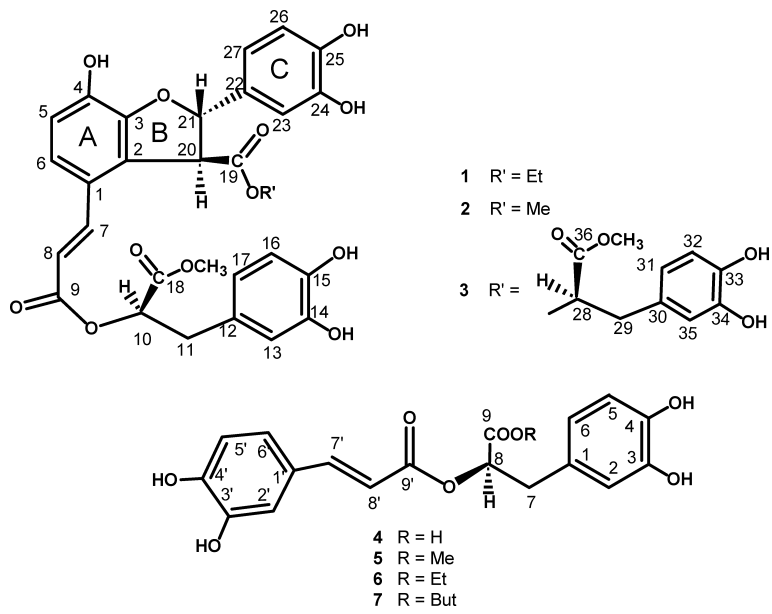

Fig. 1. Structures of Compounds $\mathbf{1}-\mathbf{7}$ 
Table 1. Activities of Compounds $\mathbf{1}-\mathbf{7}\left(\mathrm{IC}_{50} \mathrm{~mm}\right)$ in Various Antioxidant Assays

\begin{tabular}{lccc}
\hline \hline \multicolumn{1}{c}{ Compound } & $\begin{array}{c}\text { DPPH radical } \\
\text { scavenging } \\
\text { activity }\end{array}$ & $\begin{array}{c}\text { Superoxide } \\
\text { anion scavenging } \\
\text { activity }\end{array}$ & $\begin{array}{c}\text { Iron } \\
\text { chelating } \\
\text { assay }\end{array}$ \\
\hline Ethyl lithospermate (1) & 0.1028 & $-b)$ & - \\
Dimethyl lithospermate (2) & 0.1197 & - & - \\
Methyl lithospermate B (3) & 0.0506 & 0.113 & 0.053 \\
Rosmarinic acid (4) & 0.0801 & 0.282 & 0.034 \\
Metyhl rosmarinate (5) & 0.1456 & 0.443 & 0.092 \\
Ethyl rosmarinate (6) & 0.0412 & - & - \\
Butyl rosmarinate (7) & 0.2706 & - & - \\
3-t-Butyl-4-hydroxyanisole ( $^{a)}$ & 0.0442 & - & - \\
Propyl gallate $^{a)}$ & 0.03 & 0.106 & 0.064 \\
\hline
\end{tabular}

a) Standard reference compound. b) Inactive.

chine in $\mathrm{MeOH}$ solutions. IR spectra were recorded as $\mathrm{KBr}$ discs on a JASCO A-302 spectrometer. ${ }^{1} \mathrm{H}-(500 \mathrm{MHz})$ and ${ }^{13} \mathrm{C}-\mathrm{NMR}(125 \mathrm{MHz})$ spectra were recorded in $\mathrm{CD}_{3} \mathrm{OD}$ solutions on a Bruker AV-500 machine with tetramethylsilane (TMS) as an internal standard and the data is given in $\delta$ (ppm). 2D NMR spectra were taken on a Bruker AMX 500 NMR spectrometer. Electron impact mass spectra (EI-MS) were taken at $70 \mathrm{eV}$ on a Finnigan MAT-112 or MAT-312 instrument and major ions are presented as $m / z$ (\%). Fast bombardment (FAB)-MS were measured as glycerol matrix on a JEOL HX110 Mass spectrometer. TLC purification was carried out on precoated silica gel cards (E. Merck) and the spots were observed first under UV $(254 \mathrm{~nm})$ and then sprayed with cerium(IV)sulfate reagent and heated until coloration developed. Recycling preparative HPLC (RPHPLC) was used for final purification (JAI LC-908W, Japan Analytical Industry Co. Ltd.) with a column YMC ODS H-80 or L-80 (YMC, Japan).

Plant Material Whole plants of Lindelofia stylosa (KAR. \& KIR.) were collected from Britswarr Gali, Leepa Valley, Azad Kashmir, Pakistan, in September-October 2002 by Prof. Shafiq-ur-Rehman, Department of Botany, University of Azad Jammu \& Kashmir (voucher specimen No AJKUH-786165).

Extraction and Isolation Air-dried and powdered Lindelofia stylosa ( $3 \mathrm{~kg}$ ) was extracted thrice (each for one week) with $\mathrm{MeOH}(61)$ at room temperature. The resulting $\mathrm{MeOH}$ extract $(\mathrm{ca} .150 \mathrm{~g})$ was partitioned between hexane, EtOAc, $n$-butanol and water to obtain 15, 24, 50 and $40 \mathrm{~g}$ of extracts, respectively. The EtOAc fraction was chromatographed on a silica gel column and eluted with hexane, hexane-EtOAc $(1: 1,2 \times 500 \mathrm{ml})$, EtOAc $(100 \%, \quad 2 \times 750 \mathrm{ml}), \quad$ EtOAc-MeOH $\quad(2: 1, \quad 2 \times 500 \mathrm{ml})$ and EtOAc-MeOH $(1: 1,2 \times 750 \mathrm{ml})$. Fraction eluted at EtOAc-MeOH $(2: 1$, $3.5 \mathrm{~g})$ was again chromatographed on a silica gel column with acetone $-\mathrm{CHCl}_{3}(20$ to $80 \%, 2 \times 300 \mathrm{ml})$ to obtain seven fractions, among which fractions 3 and $4(350 \mathrm{mg})$ were combined and subjected to purification on a recycling preparative HPLC (RPHPLC) to obtain compound 3 (40 mg, $1.33 \times 10^{-3} \%, t_{\mathrm{R}} 52 \mathrm{~min}$ ), using $\mathrm{H}_{2} \mathrm{O}-\mathrm{MeOH}(1: 1) ; \mathrm{H}-80$ column with flow rate of $4 \mathrm{ml} / \mathrm{min}$. The fraction eluted at MeOH-EtOAc; $1: 1(5.0 \mathrm{~g})$ from silica gel column chromatography was passed through a polyamide column and eluted with $\mathrm{CHCl}_{3}$ with increasing proportions of methanol.

Among these, two fractions, 7-12 and 16-20, obtained by solvent gradient of $10-25 \% \mathrm{MeOH}-\mathrm{CHCl}_{3}$ were combined and subjected to RPHPLC purification. The use of ODS chromatography (L-80 column) on HPLC of fr. $7-12(310 \mathrm{mg})$ using $\mathrm{H}_{2} \mathrm{O}-\mathrm{MeOH}(1: 1)$ as a mobile phase at a flow rate of $4 \mathrm{ml}$ resulted into two unresolved fractions $\mathrm{A}$ and $\mathrm{B}$. These fractions were subjected again to RPHPLC with modified separation conditions using a H80 column, $\mathrm{H}_{2} \mathrm{O}-\mathrm{MeOH}(1: 2)$ and flow rate of $3 \mathrm{ml}$ per min, for isolation of compound $5 t_{\mathrm{R}}$ time $30 \mathrm{~min}\left(120 \mathrm{mg}, 4.0 \times 10^{-3} \%\right)$. Compounds $6(110 \mathrm{mg}$, $\left.3.66 \times 10^{-3} \%\right)$ and $7\left(20 \mathrm{mg}, 6.66 \times 10^{-4} \%\right)$ were isolated under the similar RPHPLC conditions as those of compound $\mathbf{5}$ with retention time of 38 and $56 \mathrm{~min}$. respectively. Both of these compounds were obtained from fraction B. Fractions $16-20$ from polyamide column $(162 \mathrm{mg})$ when subjected to RPHPLC with $\mathrm{H}_{2} \mathrm{O}-\mathrm{MeOH}(1: 2)$ as a mobile phase, $\mathrm{H}-80$ column and a flow rate of $3 \mathrm{ml}$ per min, resulted in the isolation of compounds $2(15 \mathrm{mg}$, $\left.5.0 \times 10^{-4}\right)$ and $\mathbf{1}\left(20 \mathrm{mg}, 6.66 \times 10^{-4}\right)$.

A part of the $n$-butanolic fraction $(15 \mathrm{~g})$ on treatment with HP-20 resin followed by polyamide column chromatography on $15-25 \% \mathrm{MeOH}-\mathrm{CHCl}_{3}$ afforded a fraction $(3 \mathrm{~g})$ which was treated with Sephadex LH-20 and finally with RPHPLC on an L-80 column using $\mathrm{H}_{2} \mathrm{O}-\mathrm{MeOH}(1: 1)$ as a mobile phase to yield rosmarinic acid (4) $\left(180 \mathrm{mg}, 6.0 \times 10^{-3}\right)$ and some unidentified compounds.

Ethyl Lithospermate (1): $\mathrm{C}_{30} \mathrm{H}_{28} \mathrm{O}_{12}$ : Brown yellow gum, $[\alpha]_{\mathrm{D}}^{23}+65.6^{\circ}$ $(c=0.25, \mathrm{MeOH}) ; \mathrm{UV}(\mathrm{MeOH}) \lambda_{\max }(\log \varepsilon 309$ (3.46), 290 (3.46), 254 (3.46), 224 (3.56), 197 (3.84), 194 (5.04) nm; IR (KBr) $v_{\max }$ 3300, 2933, $1722,1608,1517,1444,1265,1166 \mathrm{~cm}^{-1}$; HR FAB-MS (-ve) $m / z 579.1493$ $\left(\mathrm{M}^{+}-1\right)$; EI-MS $m / z 321$ (6.7\%), 280 (27.6\%), $123(100 \%), 77$ (34.7\%); ${ }^{1} \mathrm{H}-$ NMR $\delta\left(\mathrm{CD}_{3} \mathrm{OD}, 500 \mathrm{MHz}\right): \delta 7.71(\mathrm{~d}, J=15.9 \mathrm{~Hz}, \mathrm{H}-7), 7.19(\mathrm{~d}, J=8.4 \mathrm{~Hz}$, H-6), 6.82 (d, $J=8.4 \mathrm{~Hz}, \mathrm{H}-5$ ), $6.5-7.0$ (overlap., H-27), 6.5-7.0 (overlap., H-23), 6.5-7.0 (overlap., H-17), 6.5-7.0 (overlap., H-26), 6.5-7.0 (overlap., H-16), 6.5-6.9 (overlap., H-13), 6.28 (d, $J=15.9 \mathrm{~Hz}, \mathrm{H}-8), 5.16$ (m, H10), 5.88 (d, $J=4.8 \mathrm{~Hz}, \mathrm{H}-21), 4.41$ (d, $J=4.8 \mathrm{~Hz}, \mathrm{H}-20), 4.14$ (q, $J=14.2$, $\left.7.0 \mathrm{~Hz}, \mathrm{OCH}_{2}\right), 3.68(\mathrm{~s}, \mathrm{OMe}), 3.02(\mathrm{~m}, \mathrm{H}-11), 1.19$ (t, $J=7.0 \mathrm{~Hz}$, $\left.\mathrm{OCH}_{2} \mathrm{CH}_{3}\right) \cdot{ }^{13} \mathrm{C}-\mathrm{NMR}: \delta\left(\mathrm{CD}_{3} \mathrm{OD}, 125 \mathrm{MHz}\right): \delta 173.6(\mathrm{C}-19), 171.6(\mathrm{C}-18)$, 168.0 (C-9), 148.8 (C-3), 146.8 (C-14), 146.6 (C-24), 146.2 (C-4), 145.4 (C25), 145.4 (C-15), 144.1 (C-7), 133.3 (C-22), 128.7 (C-12), 127.0 (C-2), 124.4 (C-1), 121.9 (C-17), 121.8 (C-6), 118.4 (C-27), 118.3 (C-5), 117.5 (C13), 116.4 (C-8), 116.4 (C-26), 116.3 (C-16), 113.4 (C-23), 88.5 (C-21), $74.8(\mathrm{C}-10), 62.4\left(\mathrm{OCH}_{2}\right), 57.3(\mathrm{C}-20), 53.2(\mathrm{OMe}), 37.8(\mathrm{C}-11), 14.3$ $\left(\mathrm{OCH}_{2} \mathrm{CH}_{3}\right)$.

DPPH Radical Scavenging Assay The assay was performed according to the method developed by Lee et al. ${ }^{22)}$ Five microliters of each sample was dissolved in DMSO and mixed with $95 \mu \mathrm{l}$ of DPPH in ethanol. The concentration of DPPH was maintained at $300 \mathrm{~mm}$ with variable concentrations of sample. The mixture was dispersed in a 96-well plate and incubated at $37^{\circ} \mathrm{C}$ for $30 \mathrm{~min}$. The absorbance at $515 \mathrm{~nm}$ was measured by microtitre plate reader (Spectramax plus 384 Molecular Device, U.S.A.), and percent radical scavenging activity was determined in comparison with the DMSO-treated control (3-t-butyl-4-hydroxyanisole).

Superoxide Anion Scavenging Assay The reaction mixture was prepared by mixing $280 \mu \mathrm{m} \beta$-nicotinamide adenine dinucleotide reduced form (NADH), $80 \mu \mathrm{M}$ nitroble tetrazolium (NBT), $8 \mu \mathrm{M}$ phenazine methosulphate (PMS) and various concentrations of test samples in $200 \mu \mathrm{l}$ of $0.1 \mathrm{M}$ phosphate buffer ( $\mathrm{pH} 7.5)$. The NBT, NADH and PMS solutions were prepared in the same buffer. Test samples were dissolved in DMSO. The reaction was performed in 96-well microtitre plates at room temperature and absorbance was measured at $560 \mathrm{~nm}^{23}$ )

Measurement of $\mathrm{Fe}^{2+}$ Chelating Ability $\mathrm{The} \mathrm{Fe}^{2+}$ chelating ability was determined according to the modified method of Decker and Welch. ${ }^{24)}$ The concentrations of $\mathrm{Fe}^{2+}$ ion were measured from the formation of ferrous ion-ferrozine complex. The pure compounds (31.25 to $1 \mathrm{mM})$ were mixed with $0.4 \mathrm{mM} \mathrm{FeCl}_{2}$ and $1 \mathrm{~mm}$ ferrozine (ratio $10: 1: 2$ ). The mixture was shaken and left at room temperature for 10 mins. The absorbance of the resulting mixtures were measured at $562 \mathrm{~nm}$ by microtitre plate reader. A lower absorbance of the reaction mixture indicated a higher $\mathrm{Fe}^{2+}$-chelating ability.

Acknowledgments The authors are grateful to the Luminar and Gold Electronics (LG), Pakistan, for financial support to Afshan Begum. They also gratefully acknowledge the useful suggestions of Prof. Y. Tsuda, Visiting Professor at the H.E.J. Research Institute of Chemistry (Kanazawa University, Kanazawa, Japan).

\section{References}

1) Asibal C. F., Glinski J. A., Gelbanum L. T., Zalkow L. H., J. Nat. Prod., 52, 109 (1989).

2) Zalkow L. H., Bonetti S. J., Gelbanum L. T., Gordon M. M., Patill B. B., Shani A., Van Derveer D., J. Nat. Prod., 42, 603 (1979).

3) Men'shikov G. P., J. Gen. Chem., USSR (Engl. Transl.), 11, 209 (1941).

4) Men'shikov G. P., J. Gen. Chem., USSR (Engl. Transl.), 15, 225 (1945).

5) Men'shikov G. P., J. Gen. Chem., USSR (Engl. Transl.), 17, 343 (1947).

6) Men'shikov G. P., J. Gen. Chem., USSR (Engl. Transl.), 18, 1736 (1948).

7) Labenskii A. S., Men'shikov G. P., J. Gen. Chem., USSR (Engl. Transl.), 18, 1836 (1948).

8) Tsyrul'nikova L. G., Peresleni E. M., Sheinker Yu. N., Zhur. Obshch. Khim., 32, 2705-2709 (1962).

9) Kang H. S., Chung H. Y., Jung J. H., Kang S. S., Choi J. S., Arch. Pharm. Res., 20, 496-500 (1997).

10) Zhijun Wu., Mingan O., Chongren Y., Yunnan. Zhiwu. Yanjiu., 21, 


$$
512-516 \text { (1999). }
$$

11) Kelley C. J., Mahajan J. R., Brooks C., Newbert L. A., Breneman W. R., Carmack M., J. Org. Chem., 40, 1804-1815 (1975).

12) Kelley C. J., Harruff R. C., Carmack M., J. Org. Chem., 41, 449-455 (1976).

13) Kuo Y. H., Lee S. M., Lai J. S., J. Chin. C. Soc., 47, 241-246 (2000).

14) Hou Z. F., Tu Y. Q., Li Y., J. Chin. C. Soc., 49, 255-258 (2002).

15) Haung H., Chao Q. R., Tan R. X., Sun H. D., Wang D. C., Ma J., Zhao S. X., Planta Med., 65, $92-93$ (1999).

16) Lamaison J. L., Petitjean-Freytet C., Carnat A., Ann. Pharm. Fr., 48, 103-108 (1990).

17) Psotova J., Lasovsky J., Vicar J., Biomed. Papers, 147, 147-153 (2003).

18) Al-Sereiti M. R., Abu-Amer K. M., Sen P., Indian J. Exp. Biol., 37,
124-130 (1999).

19) Engleberger W., Hadding U., Etschenberg E., Graf E., Leyck S., Winkelmann J., Parnham M. J., Int. J. Immunopharmacol., 10, 729737 (1988).

20) Peake P. W., Pussell B. A., Martyn P., Timmermans V., Charlesworth J. A., Int. J. Immunopharmacol., 13, 853-857 (1991).

21) Naomi O., Akiko Y., Midori N., Toshikazu Y., Carcinogenesis, 25, 549-557 (2004).

22) Lee S. K., Zakaria H., Chung H., Luvengi L., Gamez E. J. C., Mehta R. J., Kinghorn D., Pezzuto J. M., Combinatorial Chemistry and High Throughput Screening, 1, 35-46 (1998).

23) Gaulejac N. S. C., Glories Y., Vivas N., Food Research International, 32, 327-333 (1999).

24) Decker E. A., Welch B., J. Agric. Food Chem., 38, 674-677 (1990). 